\title{
The Use of Correspondence Analysis in Assessing the Antecedents of Innovativeness in Public Hospitals
}

\author{
Joanna Anna Jończyk ${ }^{1}$, Anna Małgorzata Olszewska ${ }^{1}$ \\ 1 Faculty of Management, Bialystok University of Technology, Poland
}

\begin{abstract}
The aim of the study presented in this article is to show correspondence analysis as a method useful in the diagnosis of coexistence of category variables in antecedents of innovativeness, with the positions of the respondents representing various medical professions in hospitals. Primary data obtained in the course of empirical research, carried out using a questionnaire study on a sample of 459 respondents representing 8 public hospitals in Poland, is used to this aim. To follow up on the achievements of the analysis, literature on the issue of innovativeness and its antecedents was also used. The results of the correspondence analysis allows one to confirm the thesis of the different opinions of doctors, nurses/midwives and managers regarding the level of significance of antecedents of innovativeness, where for doctors and managers in this context the most important is financial optimization, and for nurses the improvement of the quality of medical services. The results may provide an important clue to the chief executives of hospitals in the context of further changes and innovativeness necessary to achieve the desired efficiency of these organizations.
\end{abstract}

\section{Introduction}

Both achievements of theory and management practices increasingly confirm that innovativeness is a key element in the success of today's organizations. This statement also applies to public hospitals (Djellal et al., 2007). These organizations, like businesses, need to continually seek out innovative advancements in order to survive. At the same time, innovativeness in public hospitals is much more complicated because it is associated with a specific form of property and concerns specific services which health services provide (Fraczkiewicz-Wronka, 2009; Williams, 2011). In view of the foregoing, it should be emphasized that in the literature a multi-dimensional approach to innovativeness prevails, reflecting the complex nature of the phenomenon, making it difficult to formulate a clear definition. One of 
the first attempts on the determination of innovation was taken by Hurt, treating it as a willingness to change (Hurt et al., 1977). Berthon presented innovation as a set of personal characteristics, such as openness, entrepreneurship, willingness to change, and the ability to innovate and be creative (Berthon et al., 1999; Blake et al., 2003; Hurley et al., 1998; Jończyk, 2013, 2015). On the other hand, Goldsmith and Hofacker treat innovation in the category of attitudes and behaviors (Goldsmith et al., 1991). For the purposes of this publication, innovativeness is defined as the openness and readiness of the organization to undertake any new phenomena (ideas, processes, products or services). At the same time, it is important to find an approximation of the term antecedents of innovativeness. Generally, they are preassumptions preceding the emergence of innovativeness. However, there is a gap in the literature regarding the study on antecedents of innovativeness, especially in public hospitals. A few studies conducted in individual public hospitals suggest that the primary antecedents of innovativeness may include orientation on the quality of medical services, the development, the formation of pro-innovation behavior of staff, and optimization of finance, which in turn are associated with market orientation, orientation to learn or orientation on entrepreneurship (Lumpkin et al., 1996; Slater et al., 1994). Therefore, this paper attempts to identify links between opinions of representatives of various professional groups regarding the antecedents of innovativeness in hospital with the positions they hold. It was assumed that due to the existence of a variety of professional subcultures in hospitals, persons representing various positions may differently assess premises (antecedents) of innovativeness, which in turn can complicate the management of processes of change in these organizations. An analysis of correspondence was accepted as the most appropriate data analysis technique in the context of the objective of the research. It is a statistical method belonging to a group of multivariate techniques, created in psychology (Stanimir, 2005, Walesiak et al., 2009). This method gained popularity thanks to M. J. Greenacre's Theory and Applications of Correspondence, published in 1984 (Greenacre, 1984), in which the author presented the technical side of this method by presenting numerous examples in sociology. Its name was popularized in an article by Hill (1974), in which the author used the analysis, focusing his discussion on only one dimension. This method provides a graphical presentation of the coexistence of categories of variables and objects (MigałaWarchoł et al., 2008). It has a number of properties, which other factorial methods do not have. It is the only method that gives one the opportunity to put reference points representing both variables and points repre- 
senting objects in a factorial arrangement, which can detect the structural relationships between variables and objects, and thus significantly increase the possibilities for interpretation. Another advantage is the fact that the analysis of correspondence, in contrast to other types of analysis (factor analysis, discriminant analysis) can handle categorical data without compromising statistical assumptions. Hoffman and Franke (1986) note that "these methods are of little use for categorical data that arise in many applications marketing research." In addition, for example, discriminant analysis and other multivariate techniques' scaling lack the capacity to generate common spaces graphically. In addition, Hoffman and Franke (1986) observe that the clear advantage of correspondence analysis in comparison to other methods of generating graphical information for a joint is that it results in two double images, wherein the rows and columns have similar interpretations, facilitating the analysis and detection of relationships. In another approach to the graphical representation of the data, this dualism is not present. Another advantage is that the common graphical representations of data are obtained without subjecting the respondents to the cognitive burden of rating similarities. From a practical point of view, the resulting map can help in the detection of structural ties between the "rows and columns" that have similar interpretations in the attributes of the objects' matrix (Machowska-Szewczyk et al., 2010). Correspondence analysis allows both types of data analysis, qualitative and quantitative. It also does not state any requirements as to the number of observations.

Correspondence analysis has many applications not only in sociological research but also as a useful research tool in psychology, economics and medicine (Migała-Warchoł et al., 2008; Milewska et al., 2012; TobiaszAdamczyk et al., 2011). In relation to management, it is worth recalling the examples of the use of correspondence analysis to assess relationships between variables determining the level of development of pro-quality businesses with the implementation of various aspects of innovation (Olszewska, 2015), as well as measuring the quality of education in higher education (Olszewska et al., 2014). A detailed description of correspondence analysis can be found, among others, in works by Greenacre (1993, 2009) and Nenadić et al. (2007). In Polish literature, a broad discussion of correspondence analysis can be found in publications by: Panek (2009) and also Balicki (2009), Walesiak et al. (2009), Gatnar et al. (2011) and Stanimir (2005). 


\section{Methodology}

Aiming at the objective of the study, in 2014 a research study was carried out in 8 hospitals (in 2 Polish voivodeships: Podlaskie and West Pomerania). A total of 696 questionnaires were analyzed, of which 368 concerned the Podlaskie region, and 319 West Pomerania (9 questionnaires have not been assigned to any province). The study included 114 doctors, 101 managers, and 244 nurses. Other respondents represented different groups of workers within a few hospitals (midwives, orderlies, medical secretaries etc.). Therefore, for further analysis, only information gathered from the three largest occupational groups: managers, doctors, and nurses was used (a total of 459 questionnaires).

The survey questions concerned, among other things, innovation research in public hospitals. For this study, five issues related to the evaluation of antecedents of innovation in hospitals were selected. They concerned orientation of the hospital towards: (1) the quality of medical services, (2) development of the individual through the implementation of change and innovation, (3) pro-innovation values and behavior of employees, and (4) financial optimization. The possible replies to these issues were: "very weak", "weak", "moderate", "strong", "very strongly", with an additional answer of "no opinion".

In the first step of the analysis, we examined the relations between the variables and the positions of the staff who responded. Due to the nature of the nominal test, an independent chi-square was applied. The purpose of such analysis was carried out to exclude those variables that are not clearly differentiated in relation to particular groups of workers. We selected only those variables that showed a clear correlation with the feature position for further analysis.

The next step of the adopted method was to make a correspondence analysis. As previously indicated in the introduction, the method of correspondence allows one to obtain results that can be presented graphically in the form of graphs made on the basis of tables of two-dimensional crosssection space factors. This creates maps of perception. By the same token, there are two types of points, objects and variables, using the coordinates of the main. Analysis of system points representing variables or objects in geometrical terms allows you to visually capture the overall accuracy of the systems of these variables or objects. Analyzing the results of the position of points relative to the center of the coordinate system (central projection) should be considered, as well as the location in relation to each other of points representing the objects relative to the points representing variables 
and vice versa. Analysis of the position of points representing the characteristics of the opinions of medical personnel with respect to the order factorial reference system (the center of the coordinate system factor), allows one to compare their degree of differentiation in relation to the antecedents of innovativeness.

\section{Results}

At the first stage of the analysis, the chi-square test of independence was performed. The results of this test are shown in Table 1.

Table 1. The results of the chi-square test of independence for the named variables and the employee's position

\begin{tabular}{|l|c|c|c|}
\hline \multicolumn{1}{|c|}{ Variable } & $\begin{array}{c}\text { statistics } \\
\text { chi-square }\end{array}$ & $\begin{array}{c}\text { degrees of } \\
\text { freedom }\end{array}$ & p-value \\
\hline Improving the quality of medical services & 37.774 & 10 & 0.0004 \\
\hline $\begin{array}{l}\text { Development of the hospital through } \\
\text { the implementation of innovation }\end{array}$ & 33.326 & 10 & 0.0024 \\
\hline $\begin{array}{l}\text { Shaping pro-innovation attitudes and } \\
\text { behavior of staff }\end{array}$ & 37.654 & 10 & 0.0004 \\
\hline The financial optimization & 51.315 & 10 & $<0.0001$ \\
\hline
\end{tabular}

Upon analyzing Table 1, it can be seen that all variables taken into account showed a significant correlation with the position of the responding employee. It is interesting, therefore, to determine what kind of response prevailed in relation to specific questions selected in relation to studied posts. To this end, as mentioned above, correspondence analysis was used.

Summary of the analysis of correspondence in relation to assessment of the variable "quality of medical services" in combination with a variable "position" is shown in Table 2 (row variable) and Table 3 (column variable).

Analysis of the prevalence of variants of answers to the question concerning the assessment of the quality of medical services (column "Mass" in Table 2), indicates that as many as $48 \%$ of respondents answered "very strong". Almost half less, approximately $22 \%$ of respondents, assessed this issue at the level of "strong", and $16 \%$ assessed this issue as "moderate". The fewest indicated "no opinion" (approx. $2 \%$ of respondents), followed by "very weak" (4\%) and "weak" (7\%). 
Table 2. Summary of the variable line in correspondence analysis for assessing the "quality of medical services" in combination with a variable "position"

\begin{tabular}{|l|c|c|c|c|c|c|c|c|c|}
\hline \multicolumn{1}{|c|}{$\begin{array}{c}\text { Row } \\
\text { name }\end{array}$} & $\begin{array}{c}\text { Coordin. } \\
\text { Dim.1 }\end{array}$ & $\begin{array}{c}\text { Coordin. } \\
\text { Dim.2 }\end{array}$ & Mass & Quality & $\begin{array}{c}\text { Relative } \\
\text { Inertia }\end{array}$ & $\begin{array}{c}\text { Inertia } \\
\text { Dim.1 }\end{array}$ & $\begin{array}{c}\text { Cosine2 } \\
\text { Dim.1 }\end{array}$ & $\begin{array}{c}\text { Inertia } \\
\text { Dim.2 }\end{array}$ & $\begin{array}{c}\text { Cosine2 } \\
\text { Dim.2 }\end{array}$ \\
\hline no opinion & -0.9317 & 0.7102 & 0.0177 & 1.0000 & 0.2907 & 0.2470 & 0.6325 & 0.4180 & 0.3675 \\
\hline v.weak & -0.3755 & -0.1458 & 0.0419 & 1.0000 & 0.0816 & 0.0952 & 0.8689 & 0.0419 & 0.1311 \\
\hline weak & -0.5313 & 0.0519 & 0.0728 & 1.0000 & 0.2489 & 0.3312 & 0.9906 & 0.0092 & 0.0094 \\
\hline moderate & 0.0271 & 0.0061 & 0.1634 & 1.0000 & 0.0015 & 0.0019 & 0.9527 & 0.0003 & 0.0473 \\
\hline strong & -0.1134 & -0.2019 & 0.2208 & 1.0000 & 0.1420 & 0.0457 & 0.2396 & 0.4224 & 0.7604 \\
\hline v.strong & 0.1893 & 0.0691 & 0.4834 & 1.0000 & 0.2353 & 0.2789 & 0.8825 & 0.1082 & 0.1175 \\
\hline
\end{tabular}

Table 3. Summary of column variable in correspondence analysis for assessing the relation between "quality of medical services" in combination with a variable "position"

\begin{tabular}{|l|r|r|l|l|l|l|l|l|l|}
\hline $\begin{array}{c}\text { Column } \\
\text { name }\end{array}$ & $\begin{array}{c}\text { Coordin. } \\
\text { Dim.1 }\end{array}$ & $\begin{array}{c}\text { Coordin. } \\
\text { Dim.2 }\end{array}$ & Mass & Quality & $\begin{array}{c}\text { Relative } \\
\text { Inertia }\end{array}$ & $\begin{array}{c}\text { Inertia } \\
\text { Dim.1 }\end{array}$ & $\begin{array}{c}\text { Cosine2 } \\
\text { Dim.1 }\end{array}$ & $\begin{array}{c}\text { Inertia } \\
\text { Dim.2 }\end{array}$ & $\begin{array}{c}\text { Cosine2 } \\
\text { Dim.2 }\end{array}$ \\
\hline doctor & -0.2980 & 0.1834 & 0.2494 & 1.0000 & 0.3663 & 0.3569 & 0.7254 & 0.3936 & 0.2746 \\
\hline nurse & -0.0344 & -0.1354 & 0.5320 & 1.0000 & 0.1246 & 0.0102 & 0.0607 & 0.4578 & 0.9393 \\
\hline manager & 0.4240 & 0.1204 & 0.2185 & 1.0000 & 0.5091 & 0.6329 & 0.9254 & 0.1486 & 0.0746 \\
\hline
\end{tabular}

With regard to posts, more than half of the respondents, approximately $53 \%$, were employed as nurses. Much fewer, nearly $25 \%$ of them, were doctors and approximately $22 \%$ were managers. Systematic analysis of the proportion of individual positions in relation to the remaining questions is the same, and the small differences stem from the fact that in the analyzed questions, a lack of response occasionally popped up.

On the basis of information concerning the inertia of the first dimension of the line variable concerning opinion on the quality of medical services (Table 2), it can be seen that the largest share in its creation was attributable to the answer "weak", "very strong" and "no opinion". A second dimension creation was primarily due to responses of "strong" and "no opinion". The first dimension explains $99 \%$ of inertia for answers "weak" and $95 \%$ for "moderate". Extreme indications: "very weak" and "very strong" are also strongly correlated with the size of the first (inertia at the level of $87 \%$ and $88 \%$ ). And only answers of "strong" show a high correlation (76\%) with the second dimension. 
From the post point of view (Table 3), it can be concluded that the first dimension is mainly defined by the managers, and the second dimension by nurses. The opinion of doctors, although responsible for development of both dimensions to a similar extent, is more strongly correlated with a first dimension. This dimension on the other hand, explained the variability of the doctors in almost $73 \%$ of cases. To an even greater extent, $93 \%$ of this dimension explained inertia in managers' answers. The second dimension contributed, however, in explaining the diversity of nurses' responses in $94 \%$.

Therefore, in conclusion, we can say that in the first dimension, on the positive side, the answers: "very strong" or "moderate" for improving the quality of medical services and the post of manager, are most closely correlated. Within the same dimension, on the left, are the responses to the quality of medical services: "no opinion", "weak" and "very weak" and the post - doctor. With regard to the second dimension, the answers most strongly correlated with the negative are the answers "strong" and the post - nurse. To the positive side of the second dimension, it is difficult to assign both the answer and the post.

Above observed dependencies can be presented in the form of perception maps, as presented in Figure 1.

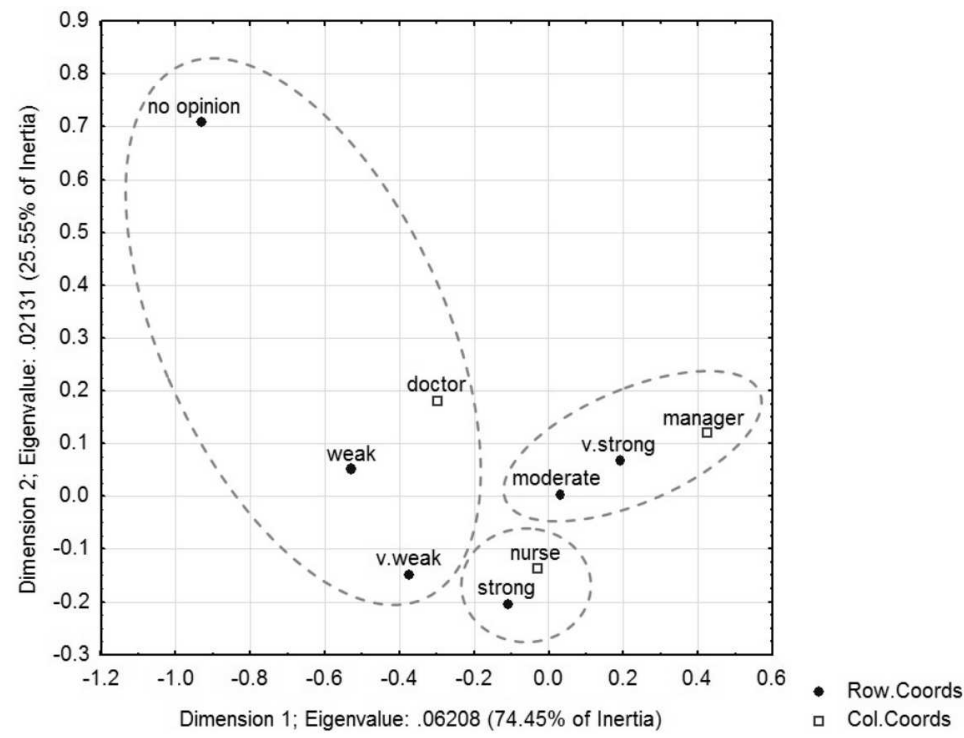

Figure 1. Map of perception linked to the characteristics of the category: "quality of medical services" and "post"

According to the description, the map of perception shows three clusters of features: (1) managers, who showed very high evaluation of quality of 
medical services, (2) nurses, who showed high evaluation of quality of medical services and (3) doctors who evaluated quality as very weak or weak or did not have an opinion.

Variation in responses of managers may stem from the fact that both departmental doctors and nurses were included in the groups.

Another analysis of the correspondence related to the evaluation of "individual development through the implementation of innovations". The summary of this variable in combination with variable "position" is shown in Table 4 (row variable) and Table 5 (column variable).

Table 4. Summary of the row variable in correspondence analysis concerning the assessment of the "development of the hospital through the implementation of innovation" in combination with a variable "post"

\begin{tabular}{|l|c|c|c|c|c|c|c|c|c|}
\hline \multicolumn{1}{|c|}{$\begin{array}{c}\text { Row } \\
\text { name }\end{array}$} & $\begin{array}{c}\text { Coordin. } \\
\text { Dim.1 }\end{array}$ & $\begin{array}{c}\text { Coordin. } \\
\text { Dim.2 }\end{array}$ & Mass & Quality & $\begin{array}{c}\text { Relative } \\
\text { Inertia }\end{array}$ & $\begin{array}{c}\text { Inertia } \\
\text { Dim.1 }\end{array}$ & $\begin{array}{c}\text { Cosine2 } \\
\text { Dim.1 }\end{array}$ & $\begin{array}{c}\text { Inertia } \\
\text { Dim.2 }\end{array}$ & $\begin{array}{c}\text { Cosine2 } \\
\text { Dim.2 }\end{array}$ \\
\hline no opinion & -0.8331 & -0.0453 & 0.0449 & 1.0000 & 0.4177 & 0.5158 & 0.9971 & 0.0064 & 0.0029 \\
\hline v.weak & -0.3347 & 0.1108 & 0.1079 & 1.0000 & 0.1790 & 0.1998 & 0.9013 & 0.0918 & 0.0987 \\
\hline weak & 0.0243 & 0.0697 & 0.1371 & 1.0000 & 0.0100 & 0.0013 & 0.1086 & 0.0462 & 0.8914 \\
\hline moderate & 0.0487 & 0.1304 & 0.2112 & 1.0000 & 0.0547 & 0.0083 & 0.1224 & 0.2492 & 0.8776 \\
\hline strong & 0.2336 & -0.0175 & 0.2966 & 1.0000 & 0.2174 & 0.2677 & 0.9944 & 0.0063 & 0.0056 \\
\hline v.strong & -0.0464 & -0.2068 & 0.2022 & 1.0000 & 0.1213 & 0.0072 & 0.0478 & 0.6002 & 0.9522 \\
\hline
\end{tabular}

Table 5. Summary of the column variable in correspondence analysis concerning the assessment of the "development of the hospital through the implementation of innovation" in combination with a variable "post"

\begin{tabular}{|l|c|c|c|c|c|c|c|c|c|}
\hline $\begin{array}{c}\text { Column } \\
\text { name }\end{array}$ & $\begin{array}{c}\text { Coordin. } \\
\text { Dim.1 }\end{array}$ & $\begin{array}{c}\text { Coordin. } \\
\text { Dim.2 }\end{array}$ & Mass & Quality & $\begin{array}{c}\text { Relative } \\
\text { Inertia }\end{array}$ & $\begin{array}{c}\text { Inertia } \\
\text { Dim.1 }\end{array}$ & $\begin{array}{c}\text { Cosine2 } \\
\text { Dim.1 }\end{array}$ & $\begin{array}{c}\text { Inertia } \\
\text { Dim.2 }\end{array}$ & $\begin{array}{c}\text { Cosine2 } \\
\text { Dim.2 }\end{array}$ \\
\hline doctor & -0.4155 & -0.0525 & 0.2472 & 1.0000 & 0.5789 & 0.7056 & 0.9843 & 0.0472 & 0.0157 \\
\hline nurse & 0.0915 & 0.1021 & 0.5371 & 1.0000 & 0.1348 & 0.0743 & 0.4450 & 0.3886 & 0.5550 \\
\hline manager & 0.2484 & -0.1941 & 0.2157 & 1.0000 & 0.2863 & 0.2201 & 0.6208 & 0.5642 & 0.3792 \\
\hline
\end{tabular}

Analysis of Table 4 regarding the frequency of answers to the question relating to the evaluation of the development of the hospital by innovation shows that the most popular answers were "strong" (30\%), "moderate" (21\%) and "very strong" (20\%). Least frequently, for only $4 \%$ of the survey respondents, the answer "no opinion" was given. 
For the two dimensional analysis of correspondence, it should be stated that the first of them was primarily shaped by the answer "no opinion" relating to the assessment of the development of the hospital, corresponding with the position of doctor, and the other by the assessment "very strong," corresponding with the positions of manager and nurse. The first dimension explained inertia of answers "no opinion", "strong" and "very weak" in 99.7\%, $99.4 \%$ and $90 \%$, respectively. The variability of the answers "very strong", "weak" and "moderate" is explained in the second dimension in 95\%, 89\% and $87 \%$. With regard to the position in conjunction with the opinion on the development of the hospital, the first explained the inertial answers of doctors in $98 \%$ and in $62 \%$ of managers. The second mainly contributed to illustrate the variability of the opinion of nurses (56\%).

Managers together with the answer "strong" form one cluster of cooccurring features found in the positive side of the first dimension, and the doctors with the answers "no opinion" and "very weak", comprise the first dimension's negative part. The second dimension's positive area was created by nurses corresponding to the answers of "weak" and "moderate". In the negative part of this dimension, the only answer was "very strong". The relations have been illustrated in the perception map shown in Figure 2.

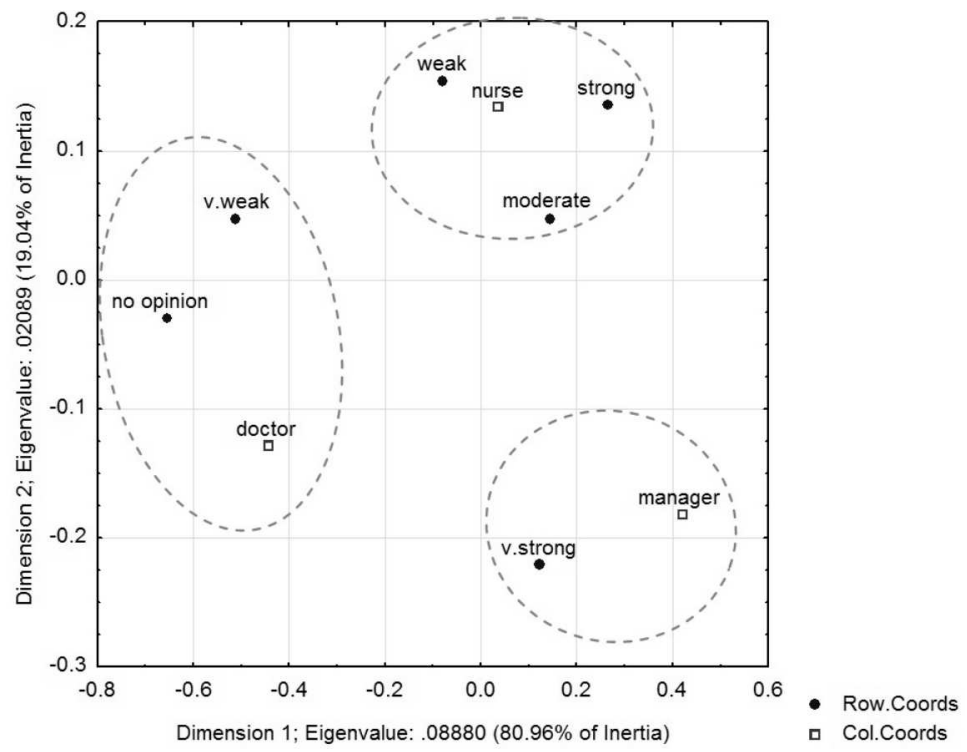

Figure 2. Map of perception with category features: "the development of the hospital through the implementation of innovation" and "post"

An analysis of the above description and the perception maps indicates three distinct clusters showing the respective characteristics: (1) doctors 
who had no opinion with respect to the issue of assessing the development of hospitals (if their answers appear, they are rather closer to "very weak"), (2) nurse assessment of "weak", "moderate" or "high", and (3) managers issuing "very high" scores.

The summary of analysis of correspondence in relation to the variable "shaping pro-innovative attitudes and behavior of employees" in combination with "post" variables is shown in Table 6 (row variable) and Table 7 (column variable).

Table 6. Summary of row variable correspondence analysis on the "development of pro-innovation attitudes and behavior of hospital staff" in combination with a variable "post"

\begin{tabular}{|l|r|r|l|l|l|l|l|l|l|}
\hline \multicolumn{1}{|c|}{$\begin{array}{c}\text { Row } \\
\text { name }\end{array}$} & $\begin{array}{c}\text { Coordin. } \\
\text { Dim.1 }\end{array}$ & $\begin{array}{c}\text { Coordin. } \\
\text { Dim.2 }\end{array}$ & Mass & Quality & $\begin{array}{c}\text { Relative } \\
\text { Inertia }\end{array}$ & $\begin{array}{c}\text { Inertia } \\
\text { Dim.1 }\end{array}$ & $\begin{array}{c}\text { Cosine2 } \\
\text { Dim.1 }\end{array}$ & $\begin{array}{c}\text { Inertia } \\
\text { Dim.2 }\end{array}$ & $\begin{array}{c}\text { Cosine2 } \\
\text { Dim.2 }\end{array}$ \\
\hline no opinion & -1.0321 & -0.0008 & 0.0487 & 1.0000 & 0.6224 & 0.6348 & 1.0000 & 0.0000 & 0.0000 \\
\hline v.weak & -0.3979 & 0.0157 & 0.0796 & 1.0000 & 0.1516 & 0.1544 & 0.9985 & 0.0119 & 0.0015 \\
\hline weak & -0.0058 & 0.0756 & 0.1460 & 1.0000 & 0.0101 & 0.0001 & 0.0058 & 0.5102 & 0.9942 \\
\hline moderate & 0.1825 & -0.0144 & 0.2478 & 1.0000 & 0.0996 & 0.1010 & 0.9938 & 0.0313 & 0.0062 \\
\hline strong & 0.1971 & 0.0184 & 0.2257 & 1.0000 & 0.1062 & 0.1074 & 0.9913 & 0.0468 & 0.0087 \\
\hline v.strong & -0.0275 & -0.0509 & 0.2522 & 1.0000 & 0.0101 & 0.0023 & 0.2254 & 0.3998 & 0.7746 \\
\hline
\end{tabular}

Table 7. Summary of column variable correspondence analysis on the "development of pro-innovation attitudes and behavior of hospital staff" in combination with a variable "post"

\begin{tabular}{|l|r|r|l|l|l|l|l|l|l|}
\hline $\begin{array}{c}\text { Column } \\
\text { name }\end{array}$ & $\begin{array}{c}\text { Coordin. } \\
\text { Dim.1 }\end{array}$ & $\begin{array}{c}\text { Coordin. } \\
\text { Dim.2 }\end{array}$ & Mass & Quality & $\begin{array}{c}\text { Relative } \\
\text { Inertia }\end{array}$ & $\begin{array}{c}\text { Inertia } \\
\text { Dim.1 }\end{array}$ & $\begin{array}{c}\text { Cosine2 } \\
\text { Dim.1 }\end{array}$ & $\begin{array}{c}\text { Inertia } \\
\text { Dim.2 }\end{array}$ & $\begin{array}{c}\text { Cosine2 } \\
\text { Dim.2 }\end{array}$ \\
\hline doctor & -0.4851 & 0.0159 & 0.2478 & 1.0000 & 0.7007 & 0.7140 & 0.9989 & 0.0382 & 0.0011 \\
\hline nurse & 0.1125 & -0.0342 & 0.5354 & 1.0000 & 0.0889 & 0.0830 & 0.9156 & 0.3816 & 0.0844 \\
\hline manager & 0.2766 & 0.0662 & 0.2168 & 1.0000 & 0.2105 & 0.2030 & 0.9458 & 0.5801 & 0.0542 \\
\hline
\end{tabular}

With regard to the issue of the formation of hospitals' pro-innovation attitudes and behavior of employees, it should be noted (Table 6) that there were more indications of "very strong" ( $25 \%$ of the respondents granted such answers), "strong" (23\%) and "moderate" (25\%). Least frequently, by only $5 \%$ of respondents, the response of "no opinion" was indicated.

Precisely those least likely indicated answers "no opinion", contributed to the first dimension, while to the second, the main contributions were the 
answers "weak" and "very strong". The first dimension, in more than 99\%, explains the inertia of each of the following responses: "no opinion", "very weak", "moderate" and "strong". The second dimension explains variations of the answers "weak" (99\%), and "very strong" (77\%). In the case of posts, only the first dimension is sufficient, which explains the inertia of the positions of doctor, manager, and nurses in, respectively, 99\%, approximately $95 \%$, and $92 \%$.

The positive part of the first dimension was comprised of the answers "moderate" and "strong" and correlated with the positions of nurse and manager, and the negative indicated "no opinion" and "very weak" and corresponded with the position of doctor. The negative part of the second dimension is completed by the answer "very strong", and the positive part consists of the answer "weak".

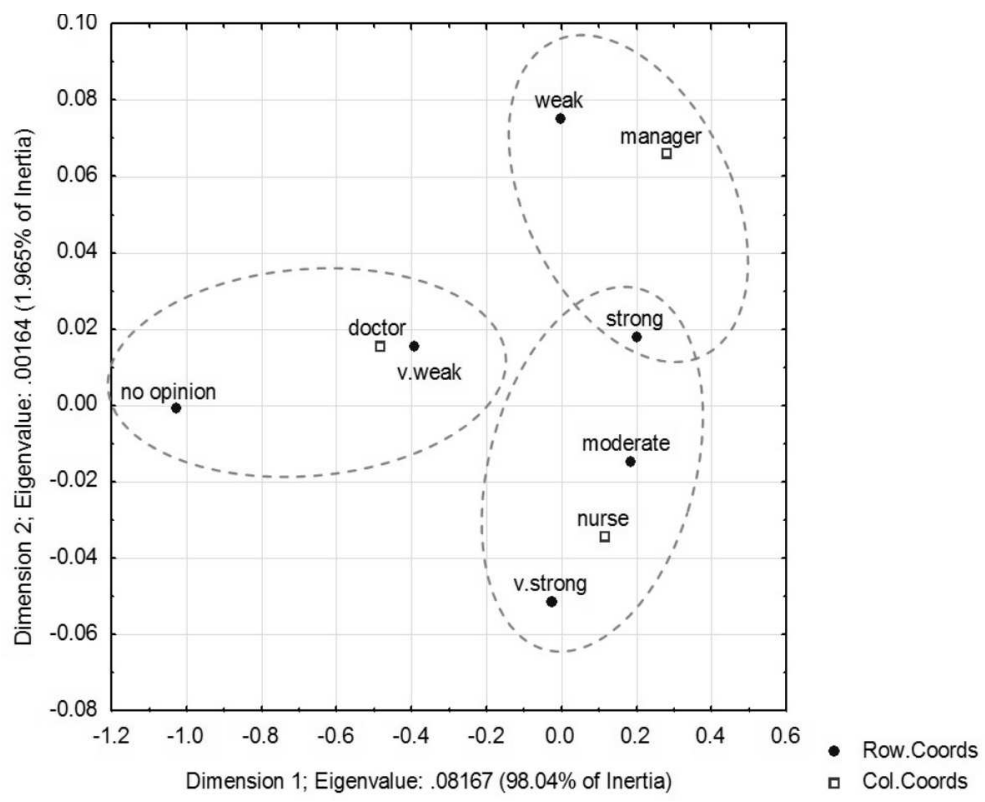

Figure 3. Map of perception of relations of characteristics: "the formation of pro-innovation attitudes and behavior of hospital staff" and "post"

The map of perception constructed during the correspondence analysis (Figure 3) also points to the three clusters: (1) the doctors who gave answers "very weak" or had no opinion (2) managers corresponding to the "weak" or "strong" and (3) nurses with the opinion of the moderate through a strong to very strong. The discrepancy in the responses of managers may result, as in the case of the first analyzed factor, from both departmental nurses and doctors belonging to a group of managers. 
The summary of analysis of correspondence in relation to the variable "optimize financial statement" with a variable "post" is shown in Table 8 (row variable) and Table 9 (column variable).

Table 8. Summary of row variable in correspondence analysis on "optimizing financial statement" with a variable "post"

\begin{tabular}{|l|c|c|c|c|c|c|c|c|c|}
\hline \multicolumn{1}{|c|}{$\begin{array}{c}\text { Row } \\
\text { name }\end{array}$} & $\begin{array}{c}\text { Coordin. } \\
\text { Dim.1 }\end{array}$ & $\begin{array}{c}\text { Coordin. } \\
\text { Dim.2 }\end{array}$ & Mass & Quality & $\begin{array}{c}\text { Relative } \\
\text { Inertia }\end{array}$ & $\begin{array}{c}\text { Inertia } \\
\text { Dim.1 }\end{array}$ & $\begin{array}{c}\text { Cosine2 } \\
\text { Dim.1 }\end{array}$ & $\begin{array}{c}\text { Inertia } \\
\text { Dim.2 }\end{array}$ & $\begin{array}{c}\text { Cosine2 } \\
\text { Dim.2 }\end{array}$ \\
\hline no opinion & 0.4136 & 0.2217 & 0.0867 & 1.0000 & 0.1674 & 0.1518 & 0.7768 & 0.2599 & 0.2232 \\
\hline v.weak & 0.3941 & -0.1264 & 0.1511 & 1.0000 & 0.2270 & 0.2403 & 0.9067 & 0.1474 & 0.0933 \\
\hline weak & 0.3253 & 0.0196 & 0.1356 & 1.0000 & 0.1263 & 0.1469 & 0.9964 & 0.0032 & 0.0036 \\
\hline moderate & -0.0221 & -0.1090 & 0.1956 & 1.0000 & 0.0212 & 0.0010 & 0.0395 & 0.1418 & 0.9605 \\
\hline strong & -0.4021 & -0.0994 & 0.1844 & 1.0000 & 0.2775 & 0.3055 & 0.9424 & 0.1111 & 0.0576 \\
\hline v.strong & -0.2473 & 0.1496 & 0.2467 & 1.0000 & 0.1807 & 0.1545 & 0.7321 & 0.3366 & 0.2679 \\
\hline
\end{tabular}

Table 9. Summary of column variable in correspondence analysis on "optimizing financial statement" with a variable "post"

\begin{tabular}{|l|c|c|c|c|c|c|c|c|c|}
\hline $\begin{array}{c}\text { Column } \\
\text { name }\end{array}$ & $\begin{array}{c}\text { Coordin. } \\
\text { Dim.1 }\end{array}$ & $\begin{array}{c}\text { Coordin. } \\
\text { Dim.2 }\end{array}$ & Mass & Quality & $\begin{array}{c}\text { Relative } \\
\text { Inertia }\end{array}$ & $\begin{array}{c}\text { Inertia } \\
\text { Dim.1 }\end{array}$ & $\begin{array}{c}\text { Cosine2 } \\
\text { Dim.1 }\end{array}$ & $\begin{array}{c}\text { Inertia } \\
\text { Dim.2 }\end{array}$ & $\begin{array}{c}\text { Cosine2 } \\
\text { Dim.2 }\end{array}$ \\
\hline doctor & -0.1068 & 0.2181 & 0.2489 & 1.0000 & 0.1287 & 0.0291 & 0.1934 & 0.7220 & 0.8066 \\
\hline nurse & 0.2629 & -0.0536 & 0.5311 & 1.0000 & 0.3353 & 0.3760 & 0.9602 & 0.0929 & 0.0398 \\
\hline manager & -0.5139 & -0.1174 & 0.2200 & 1.0000 & 0.5360 & 0.5950 & 0.9504 & 0.1850 & 0.0496 \\
\hline
\end{tabular}

In the case of the answers concerning financial optimization, it should be noted that the indications "no opinion" were spread fairly evenly. The answers "very strong" (25\%), "moderate" (20\%) and "strong" (18\%), slightly prevailed, however. Other notes "very weak" and "weak" are indicated, respectively, by $15 \%$ and $14 \%$ of respondents.

The first dimension of the analysis of correspondence has been defined mainly by the answers "strong" and "very weak" and the other by answers "very strong" and "no opinion". Inertia of most ratings in the aspect of financial optimization, beyond the response of "moderate", was explained by the first dimension (the level of inertia received more than $90 \%$ for not "weak", "very weak" and "strong" and gave "very strong" and "no opinion" in more than $70 \%$ of cases). Dispersion indicated that "moderate" was explained by the second dimension in $96 \%$. 
Upon analyzing the inertia associated with position, it should be noted that mainly the answers of managers and nurses led to construction of the first dimension and that the second dimension was comprised of medical doctors' answers. Dispersal of opinions of the latter $80 \%$ explained the second dimension, and managers and nurses explained the first dimension (inertia at the level of $95 \%$ and $96 \%$ ).

To summarize the above description, it should be noted that the positive part of the first dimension was created by the "weak" and "very weak" responses of nurses. The negative part of this dimension reflects the "strong" and "very strong" indications made by managers. In contrast, the positive part of the second dimension is made up of the answers of doctors, and negative indications of "moderate". The above considerations have been depicted on the map of perception in Figure 4.

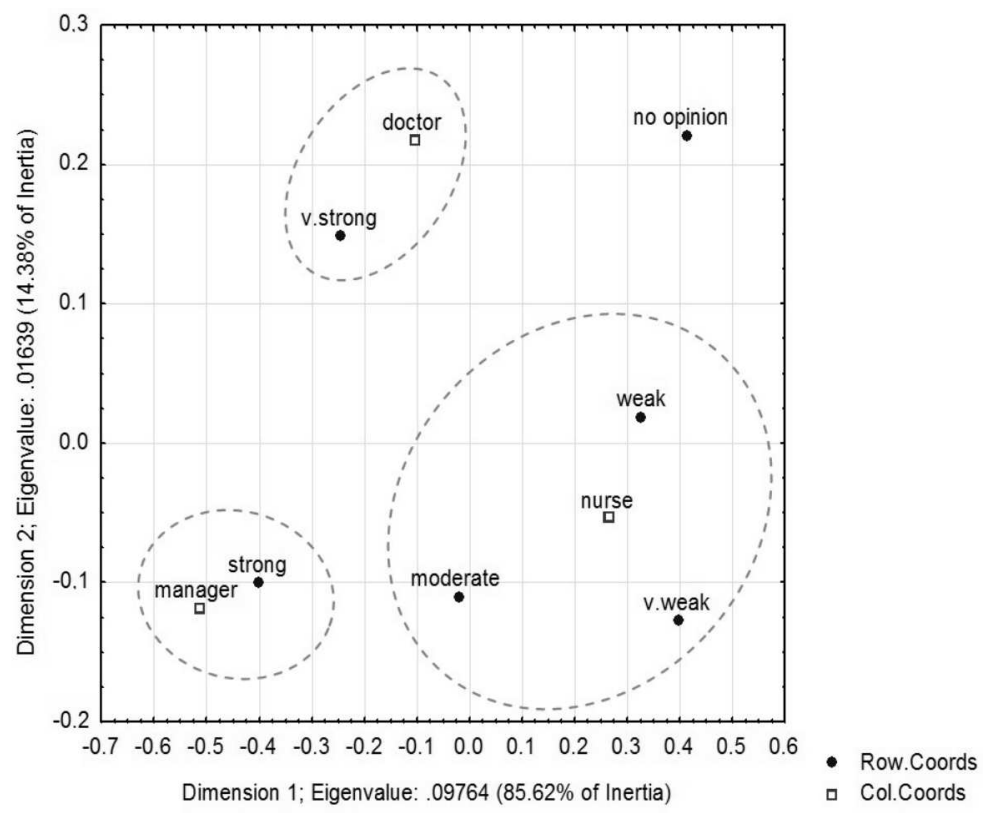

Figure 4. Map of perception of relations between category features: "financial optimization" and "post"

By analyzing the map of perception, three clusters reflecting the answers and posts can be seen: (1) managers indicating a high assessment of financial optimization (2) physicians indicating a very high assessment of the aspect and (3) nurses indicating quite diversely, but devoid of the stress response assessment. 


\section{Conclusions}

In today's competitive healthcare sector, understanding the conditions of operation of a public hospital is becoming increasingly important. Therefore, it seems necessary to analyze these conditions, including the antecedents of innovativeness in the context of current and future development needs of these organizations. In this publication, correspondence analysis is indicated as a particularly useful method in the diagnosis of coexistence of the category variables of antecedents of innovativeness and respondents occupying various positions in the studied hospitals. The results of the correspondence analysis allows one to confirm the thesis of the different opinions of doctors, nurses/midwives and managers regarding the level of significance of antecedents of innovativeness. Doctors more highly assessed the importance of financial optimization and assessed shaping pro-innovative attitudes and behavior of staff and improving the quality of medical services as lower in importance. On the other hand, they had no opinion on the significance of the development of the hospital through the implementation of innovations. Other trends can be seen in the opinions of nurses and midwives. Highly rated antecedents were such innovations as shaping pro-innovative attitudes, behavior of staff, and improving the quality of medical services, while the lower assessment related to the development of the hospital through the implementation of financial innovation and optimization. In turn, managers appreciated the importance of optimizing hospital finances, and hospital development through the implementation of innovation and shaping pro-innovative attitudes and behavior of staff. In the case of improving the quality of medical services, the opinions of managers were extreme, from weak to strong, which, as already emphasized, may stem from the fact that this group was comprised of both doctors and nurses. Thus, the above results can lead to the conclusion that there is a need to take into account the existence of subcultures and unions in the management of public hospitals. According to Legge, ignoring these subcultures is equivalent to omitting the specifics of a group of working people (Legge, 1994; Pocztowski, 2013). In the case of hospitals, where the subcultures of professional environments of doctors and nurses are often thought to be characterized by a strong and specific failure to take their opinions to the management, changes or innovations can be greatly complicated. Public hospitals especially are fairly widely regarded as the traditional systems supporting low tolerance of uncertainty. All in all, it can be concluded that the applied research method of correspondence analysis has proved to be very useful. It has allowed us to observe relationships between antecedents of innova- 
The Use of Correspondence Analysis in Assessing the Antecedents...

tiveness. At the same time, differences in opinions of particular respondents may be a good preassumption for building further pro-effective action taken by top management.

\section{Acknowledgements}

The considerations presented in this article are the result of the research project of Joanna Jończyk, $\mathrm{PhD}$, on "Shaping pro-innovation culture in the public hospitals", funded within the project NCN 2011/03/B/HS4/0454 and project S/WZ/1/2014 financed from Ministry of Science and Higher Education funds.

\section{R E F E R E N C E S}

Balicki, A. (2009). Statystyczna analiza wielowymiarowa i jej zastosowania spoteczno-ekonomiczne. Gdańsk: Wydawnictwo Uniwersytetu Gdańskiego.

Berthon, P., Hulbert, J. M., \& Pitt, L. F. (1999). To Serve or Create? Strategic Orientations toward Customers and Innovativeness. California Management Review, 42, 37-58.

Blake, B. F., Neuendorf, K. A., \& Valdiserri, C. M. (2003). Innovativeness and variety of internet shopping. Internet Research: Electronic Networking Applications and Policy, 13, 156-169.

Djellal, F., \& Gallouj, F. (2007). Innovation in hospitals: a survey of literature. The European Journal of Health Economics, 8, 181-193.

Frączkiewicz-Wronka, A. (Ed.). (2009). Zarzadzanie publiczne $w$ teorii i praktyce ochrony zdrowia. Kraków: Wolters Kluwer Polska.

Gatnar, E., \& Walesiak, M. (Eds.). (2011). Analiza danych jakościowych i symbolicznych z wykorzystaniem program R. Warszawa: Wydawnictwo C.H. Beck.

Goldsmith, R. E., \& Hofacker, C. F. (1991). Measuring consumer innovativeness. Journal of Academy of Marketing Science, 19, 209-221.

Greenacre, M. J. (1984). Theory and Applications of Correspondence. London: Academic Press.

Greenacre, M. J. (1993). Correspondence Analysis in practice. London: Bulletin of Sociological Methodology Academic Press.

Greenacre, M. J. (2009). Power transformations in correspondence analysis. Computational Statistics and Data Analysis, 53(8), 3107-3116.

Hill, M. O. (1974). Correspondence Analysis: A Neglected Multivariate Method. Journal of the Royal Statistical Society. Series C (Applied Statistics), 23(3), $340-354$.

Hoffman, D .L., \& Franke G. R. (1986). Correspondence Analysis: Graphical Representation of Categorical Data in Marketing Research. Journal of Marketing Research, 13, 213-227. 
Hurley, R. F., \& Hult, G. T. M. (1998). Innovativeness, Market Orientation, and Organizational Learning: An Integration and Empirical Examination. Journal of Marketing, 62, 42-54.

Hurt, H. Y., Joseph, K., \& Cook, C. D. (1977). Scales for the measurement of innovativeness. Human Communication Research, 4, 58-65.

Jończyk, J. A. (2013). Istota innowacji w publicznych szpitalach. Studia Ekonomiczne. Zarzadzanie publiczne: koncepcje, metody, techniki, 169, 42-51.

Jończyk, J. A. (2015). The Impact of Human Resource Management on the Innovativeness of Public Hospitals in Poland. Procedia - Social and Behavioral Sciences, 213, 1000-1007.

Legge, K. (1994). Managing culture: fact or fiction? In K. Sisson (Ed.), Personnel Management: A Comprehensive Guide to Theory and Practice in Britain (pp. 397-433). San Francisco, CA: Blackwell.

Lumpkin, G. T., \& Dess, G. (1996). Clarifying the entrepreneurial orientation construct and linking it to performance. Academy of Management Review, 21(1), $135-172$.

Machowska-Szewczyk, M., \& Sompolska-Rzechuła, A. (2010). Analiza korespondencji w badaniu osób dokonujących zakupów przez Internet. Prace Naukowe Uniwersytetu Ekonomicznego we Wroławiu. Ekonometria, 141(29), 9-20.

Migała-Warchoł, A., \& Cichocka, I. (2008). Wykorzystanie analizy korespondencji do opisu jakości życia mieszkańców województwa podkarpackiego. In $M a$ teriaty Krajowej Konferencji Naukowej. Rola informatyki w naukach ekonomicznych i społecznych, Kielce: Wyższa Szkoła Handlowa im. Bolesława Markowskiego.

Milewska, A. J., Jankowska, D., Górska, U., Milewski, R., \& Wołczyński, S. (2012). Graphical representation of the relationships between qualitative variables concerning the process of hospitalization in the gynecological ward using correspondence analysis. Studies in Logic, Grammar and Rhetoric. Logical, Statistical and Computer Methods in Medicine, 29(42), 7-25.

Nenadić, O., \& Greenacre, M. J. (2007). Correspondence Analysis in R, with twoand three-dimensional Graphics: The ca Package. Journal of Statistical Software, 20(3), 1-13.

Olszewska, A. M., \& Gryko-Nikitin, A. (2014). Pomiar postrzegania jakości kształcenia uczelni wyższej na danych porządkowych z wykorzystaniem środowiska R. Prace Naukowe Uniwersytetu Ekonomicznego we Wroławiu. Taksonomia, 328, 273-281.

Olszewska, A. M. (2015). Zastosowanie analizy korespondencji do badania związku pomiędzy zarządzaniem jakością a innowacyjnością przedsiębiorstw. Prace Naukowe Uniwersytetu Ekonomicznego we Wroławiu. Taksonomia, 385, 187194.

Panek, T. (2009). Statystyczne metody wielowymiarowej analizy porównawczej. Warszawa: Szkoła Główna Handlowa w Warszawie. 
The Use of Correspondence Analysis in Assessing the Antecedents...

Pocztowski, A. (2013). Adding Value from Human Resource Development in International Assignment. Argumenta Oeconomica Cracoviensia, 9, 9-28.

Slater, S., \& Narver, J. (1994). Does competitive environment moderate the market orientation-performance relationship? Journal of Marketing, 58, 46-55.

Stanimir, A. (2005). Analiza korespondencji jako narzędzie do badania zjawisk ekonomicznych. Wrocław: Wydawnictwo Akademii Ekonomicznej we Wrocławiu.

Tobiasz-Adamczyk, B., Brzyski, P., \& Florek, M. (2011). Wykorzystanie analizy korespondencji do określenia relacji między budżetem czasu osób starszych a subiektywną oceną stanu zdrowia. Gerontologia Polska, 19(3-4), 199-211.

Walesiak, M., \& Gatnar, E. (Eds.). (2009). Statystyczna analiza danych z wykorzystaniem programu $R$. Warszawa: PWN.

Williams, I. (2011). Organizational readiness for innovation in health care: some lessons from the recent literature. Health Service Management Research, 24, $213-218$. 